\title{
The Dark or Bright Side of Entrepreneurs' Social Capital: Effects on Creativity and Innovation
}

\author{
Barış Safran (Corresponding Author) \\ İstanbul Kültür Üniversitesi İncirli Yerleşkesi, 34158 Bakırköy, İstanbul, TURKEY \\ Tel: 9-212-498-4141Ｅ-mail: b.safran@iku.edu.tr \\ Ata Özdemirci (Associate Professor) \\ Marmara Üniversitesi Göztepe Yerleşkesi 34722 Kadıköy, İstanbul, TURKEY \\ E-mail: atademir@marmara.edu.tr
}

Received: January 27, 2020 Accepted: February 10, 2020 Published: February 21, 2020

doi:10.5296/bms.v11i1.16338 URL: https://doi.org/10.5296/bms.v11i1.16338

\begin{abstract}
Creativity and innovation phenomena, which are closely interrelated concepts with entrepreneurship, interact with entrepreneurs' social capital through their entrepreneurship and innovation ecosystems. Entrepreneurs' social capital can be influential in various ways in the creativity and innovation processes. Some studies focus on the benefits of social capital, while others focus on the current and potential negative consequences. The concepts of creativity, social capital and innovation in entrepreneurship and the relationships and connections between these variables constitute the subject of this study. All of the participants in the study were trained on entrepreneurship (511) and some of them (211) established their own business. The relational variables of the research are patent application and ownership of entrepreneur/entrepreneur candidates (as a concrete indicator of the innovation process); and independent variables are creative thinking disposition and social capital. While the social capital and creative thinking disposition levels of entrepreneurs are determined and measured by the scales, data regarding the ownership of industrial property rights (patents, utility models, etc.) are taken into consideration for innovation performance. According to the results of the analysis, it was observed that social capital had a positive effect on the creativity of entrepreneurs and innovation performance of enterprises.
\end{abstract}

Keywords: Creativity, Social Capital, Entrepreneurship, Innovation, Entrepreneurship 
Ecosystem, Innovation Ecosystem

\section{Introduction}

As the traditional economic theories have become inadequate to explain economic events and phenomena, the concept of enterprise, which gains prominence as a fourth factor of production along with labor, capital and natural resources (Mishra, 2013), brings up entrepreneurial phenomena; entrepreneur as an individual (Brouard and Larivet, 2010,p.31) and entrepreneurship as a form of action and process (Lucky, 2012,p.346). The entrepreneur, who initially was defined around capital (Smith, 2007), the willingness to take risks (Cantillon, 2010), the ability to organize and manage production inputs (Say, 2017) and the ability to identify and evaluate opportunities (Kirzner, 1973) and ability to cope with uncertainty (Knight, 2014), then became more prominent with his/her creative and innovative identity (Baudeau, 1910; Schumpeter, 1934) and the concepts of entrepreneurship and innovation started to be frequently used together (Herron and Herron, 1991). The aim of the study is to demonstrate the relationship between creativity/innovation (which are very important concepts in the entrepreneurship literature) and social capital. Entrepreneurship ecosystem, innovation systems and the social capital of the entrepreneur overlap in many points in practice and appear as a noteworthy phenomenon to examine.

By understanding the importance of innovation in micro scale - entrepreneur and enterprise and macro scale - regions and countries - in obtaining positive results in performance measures such as competitiveness, profitability and efficiency (Mowery and Oxley, 1995), concepts such as creativity, entrepreneurship ecosystem and innovation system started to be researched using different disciplines (Osorio and Buitrago, 2018). The actors in the entrepreneurship ecosystem and innovation systems with which the entrepreneurs interact; together with the family, friends, NGOs that the entrepreneurs are affiliated to and other persons, institutions and organizations with which they communicate, comprises the social capital the social capital of entrepreneurs (Theodoraki, Messeghem and Rice, 2018).

As a result of insufficient economic, financial and physical capital approaches, the concept of social capital, whose up-to-dateness has increased significantly in the last twenty years, has started to take part in the literature together with the terms such as human/cultural/intellectual capital in an attempt to increase the explanatory power of economic models on issues such as economic progress, growth and differences in development levels (Nahapiet and Ghoshal, 1998). Social capital, which makes it easier for entrepreneurs to access various opportunities through social networks, represents a financial value as well though hard to measure (Lins, Servaes and Tamayo, 2017). In addition to providing the information needed in processes such as opportunity identification and creative idea creation, social capital also facilitates access to physical, financial and other resources needed in processes such as foundation, design, prototyping and implementation (Brush, Greene, Hart and Haller, 2001).

The concepts of creativity, social capital and innovation in entrepreneurship and the relationships and connections between these variables constitute the subject of this study. The 
scope of this research is to analyze the effects of social capital on the creativity and innovation performances of entrepreneurs due to the opportunities and resources it offers.

\section{Concepts and Relationships}

\subsection{The Concepts of Entrepreneurship and Social Capital}

GEM (Global Entrepreneurship Monitor) which tracks entrepreneurship activities globally, defines entrepreneurship as an attempt by a person, a team, or an existing business to create a new enterprise by either establishing a new business or expanding an existing one (Reynolds, et al., 2005). In short, the entrepreneur refers to the individual who creates a new enterprise, entrepreneurship, refers to the process of creating a new enterprise for profit, and enterprise refers to the structure created by the entrepreneur at the end of the action process (Ahmad and Seymour, 2008). The elements of entrepreneurship are the entrepreneur (the person who creates the idea), innovation/distinctness, uniqueness, organization, teambuilding, value creation, business follow-up, growth and continuity (Ergen, 2014,p.39-41).

While there are many classifications related to the types of entrepreneurship, intrapreneurship (corporate entrepreneurship), social entrepreneurship and women's entrepreneurship are becoming particularly important in the recent years (Antoniou, Cooper and Gatrell, 2019, p.4-6). Intrapreneurship in its simplest form is expressed as taking responsibility for creating innovation within the organization (Jong and Wennekers, 2008, p.4). A woman who owns her own business in the market economy, works alone or has employees, produces and sells goods or services, researches credit resources, can cope with urgent problems related to work, adapt to new conditions and seeks to gain experience in her field can be defined as "entrepreneurial woman" (Karaömer, 2014, p. 24). On the other hand, social entrepreneurship in short taking the good aspects of commercial entrepreneurship and implementing them for social mission and purposes (Gandhi and Raina, 2018).

Entrepreneurs' funding sources are diverse, including personal savings, family and friends, commercial banks, vendor finance, angel investors, venture capital and leasing (Esterling, et al. 2009). In addition to those mentioned above, institutions and organizations that support entrepreneurs (KOSGEB, TUBITAK etc.) can be counted as other advantageous sources of funding (Yavan, 2018). Within the scope of university-industry collaboration, both universities and academicians are encouraged to engage in entrepreneurial activities and to carry out joint projects with the private sector (Healy, et al. 2014).

Entrepreneurship, which is one of the main actors of change in the globalization and information age, contributes to the economy with its functions such as organizing production, providing product diversity, providing employment, generating new markets, sales models and working capital (Audretsch, 2003). It is also functional in accelerating economic growth, increasing the welfare level and spreading it to a broad social base, strengthening the middle class, and eliminating or reducing regional development disparities (Hartmann, 2014).

Entrepreneurship ecosystem is defined as a structure in any geographic region that is formed 
by the combination of various actors (entrepreneurs, institutions and organizations) and factors (markets, regulatory framework, support setting, entrepreneurial culture), which depend on and interact with each other and evolves over time and leads to new ventures (Mason and Brown, 2014).

Fukuyama (2000, p. 3), who has made important contributions to social capital literature, defined social capital as an informal form of concrete support for cooperation based on trust between two or more individuals. Putnam (2000, p. 18), stated the concept of social capital as relationships between individuals and social networks, behavioral norms and reliability. Bourdieu (1986, p. 249) defines social capital as capital that consisted of social obligations and ties, which can be convertible into economic capital under certain conditions and institutionalized in various forms (such as a nobility).

Social capital can be converted into other types of capital; the superiorities arising from the position of an individual in social networks can transform to superiorities in economic or other matters (Milana and Maldaon, 2015). Social capital can be replaceable with other resources or complete them (Adler and Kwon, 2002).

Organizational culture and the human factor are the pillars of social capital (Melé, 2003). The sources of social capital are formed with family, non-governmental organizations, firms, public sector, ethnic and other social groups (Hudson and Chapman, 2002). In addition, concepts such as income justice, rights, law, equality, trust, neighborhood, friendship contribute positively to social capital (Düzgün, 2018). Trust, loyalty, commitment (continuance, emotional and normative commitment) and community are recognized among the elements of social capital (Kang and $\mathrm{Na}$, 2018). Besides, time and geographical proximity are resources that contribute to social capital (Fazio and Lavecchia, 2013; Foster, et al. 2017).

The types of social capital are examined under five headings: 1) Bonding-BridgingLinking (Gittell and Vidal, 1998; Woolcock, 2000-2001; Carroll, 2001; Paxton, 2002; Szreter, 2002), 2) Civil Society-Public (Collier, 1998; Leana and Van Buren III, 1999), 3) Structural-Conceptual (Tsai and Ghoshal, 1998), 4) Strong Bonds-Weak Bonds (Granovetter, 1973) and 5) Relational-System Capital (Esser, 2008).

Bonding social capital is local and inward looking approach, that lead the development of strong ties such as friendship and kinship which are helpful for getting by' but can also reinforce "exclusive identities and homogeneous groups" (family members, friendship, etc.) (Muir, 2011, p. 961). Bridging social capital is 'outward looking' social networks across different social and ethnic groups that do not necessarily share similar identities (Poortinga, 2012, p. 287). Linking social capital is the extent to which individuals build relationships with (economic, political, social) institutions and individuals who have relative power over them (e.g. to provide access to services, jobs or resources) (Hawkins and Maurer, 2010, p. 1780; Patulny and Svendsen, 2007, p. 33).

Social and human capitals, which have impacts on productivity and growth in economic 
development, are among the main intervention areas of regional policies such as infrastructure, innovation, entrepreneurship and SMEs (Barlın, 2015).

\subsection{The Concepts of Creativity and Innovation}

In general terms, creativity means producing unusual, unique but useful products (Sternberg, 2000). Torrance (1965) defines creativity as being sensitive to problems, troubles, lack of information, missing items, incompatibility and identifying problems, searching for solutions and estimating problems. Runco $(1993 ; 2004)$ states creativity as a versatile structure that includes convergent and divergent thinking, self-expression, finding and solving problems, internal motivation, interrogation approach and self-confidence.

It is known that creativity and creative thinking are a systematic and organized process. The simplest explanation of the creative thinking process comes from the model developed by Graham Wallas(1926).This model of Wallas consists of four stages: preparation, incubation, illumination and verification (evaluation) (Bentley, 1999; Sadler-Smith, 2015). The mental processes of creativity are summarized as perception, image, emotion, symbols, imagination (richness of imagination) and metaphor (Gariboldi and Catellani, 2013). Although many features are expressed by many researchers such as Lowenfeld (1957; 1960), Guilfort(1966), Torrance and Safter (1999), the four most widely accepted skills are fluency, flexibility, originality and enrichment (Baker, 2001).

The concept of innovation, which first appeared with Schumpeter (1934), according to the Oslo Manuel, the output of novel processes that very new or significantly improved in product, service, new marketing or organizational method (OECD-Eurostat, 2005, p. 16).Innovation process consists of briefly, identifying needs (opportunities), creating ideas, conceptualizing (concept), developing innovation (prototyping), implementation (production), commercialization (marketing) and learning stages (Dornberger and Suvelza G., 2012).

According to different perspectives various of innovation are classified while Oslo Manual, one of the most widely accepted, described the four categories as product (goods and services), process, marketing and organizational innovation (OECD-Eurostat, 2005).Social innovation, which has come into prominence recently, refers to the development and implementation of innovation, change and improvement activities (OECD, 2011) that will benefit the society and create social value (Chell, 2007) instead of personal welfare with "fully economic" approach (Mort, Weerawardena and Carnegie, 2003).

As stated by innovation ecosystem approach, different sources and theoretical arguments point out that there are a number of common features among patterns created by biological innovation and technological innovation (Pilinkiene and Maciulis, 2014). Organisms that work together in innovation ecosystems include scientists, product developers, business people, service providers and customers (Fransman, 2014). Technoparks that exemplify science and technology-based geographic concentrations and are areas where universities, research centers, companies, entrepreneurs and investors come together (Henriques, Sobreiro 
and Kimura, 2018).

Schumpeter $(1934 ; 1939 ; 1950)$, one of the important economists of the 20th century, has tried to put forward the dynamic mechanism of the economic system with his works and in this way he has given a special importance to the entrepreneur and innovation through the entrepreneur (Lai, Nathan, Sin Tan, and Chan,2010). In his theory of economic development, Schumpeter (1934) called the creation of new combinations "an enterprise", and the individual who would make his function "an entrepreneur". Innovation is defined as "production by new methods, new goods, new forms of organization, new supply sources, new commercial routes and new markets... (Moussa, 2018)".

\subsection{Discussion: The Dark or Bright Side of Social Capital}

Entrepreneurs need social capital as well as gathering together human and financial capital factors in the entrepreneurship process (Alexy, et al. 2012). Particularly in the establishment phase of small enterprises, there is a large share of family and kinship relationships among the financial and social capital resources of entrepreneurs. It is also known that entrepreneurs who are members of a social community get more opportunities and are more successful in their businesses under favour of their connections (Hambrick and Mason, 1984; Cooper, Gimeno-Gascón and Woo, 1997; Stuart and Sorenson, 2006).

Human capital and social capital contribute positively to increase creativity and innovation (Sertkaya and Özcan, 2017; Cabello-Medina, Lo'pez-Cabrales and Valle-Cabrera, 2011). The societies with low levels of confidence, people's ability to plan for the future is reduced, they cannot find a comfortable working environment and cannot expose their creative abilities (Tura and Harmaakorpi, 2005). In the organizational structures with low levels of trust and social capital, these are the observed cases: risk aversion, non-participation in decision-making processes, mistrustfulness and resistance to innovation and change, low performance and low organizational commitment (Erdem, 2003). Researchers indicate that the large amount of strong ties between different groups supports the creativity, which is often a social process, by reducing conflicts in organizations (Ferlander, 2007).

In the innovation culture of a society, region or business, the contribution of trust-based relations, cooperation and collaboration, or in other words, the role of social capital in innovative formations, is very important (Carnall, 2007; Çalışkan, 2010; Westlund, 2013). A coherent innovation system should include customer-manufacturer-supplier and service providers-competitors and science-industry collaboration. The quality of relations in the country or region where it is applied for its success is also gaining importance (Cohen and Fields, 1999; Chakrabarti and Santoro, 2004). Providing external information to organization contributes to the innovative structure of the company(Ahn and Kim, 2017).

In addition to the studies that show the benefits of social capital on creativity, there are some studies that draw attention to some negative effects of social capital (Narayan, 
1999). Social capital has a number of negative effects such as the exclusion of outsiders, excessive demands on group members, the limitation of individual freedoms and the spread of negative group norms (Newman and Ann Dale, 2005; Banks, 2003). While social norms and social identity have a positive effect on group performance, these characteristics may prevent the group from being open to new information and different methods (Fine, 2010; Staveren and Peter Knorringa, 2007). When personal success narratives become disruptive to group integrity, downwardleveling norms (Portes, 1998, p. 15) can prevent an individual from progressing (Dinovitzer, 2006, p.447).

Gargiulo and Benassi (2000) pointed out the consequences of the solidarity phenomenon of social capital that might have negative effects on creativity such as inertia, dimsightedness, stopping new ideas and excessive loyalty preventing individuals from acknowledge the facts. Similarly, Prusak and Cohen (2001) highlighted the dangers of lack of creativity and unquestioned commitment which causes to restrain people from asking critical questions. The high density of social networks can hinder the autonomy and creativity of individuals to the extent that it increases reconciliation (Eşki, 2010; Özdemir, 2007). Shi et al. (2015) draw attention to the potential "dark side of trust" that requires extra cost and commitment in entrepreneurial processes. In the light of the studies dealing with the positive and negative consequences of social capital, this research focuses on the relationships between entrepreneurs' social capital levels, creative thinking dispositions and industrial property rights (innovation).

\section{Method, Analysis and Findings}

\subsection{Sampling Design and Data Collection}

The research sample of the study is derived over the entrepreneurs/entrepreneur candidates who are certified by participating in Applied Entrepreneurship Training that organized in cooperation with İGESİ* (İstanbul Kültür University Department of Business Development, Industrial and Sector Relations), KOSGEB ${ }^{* *}$ (Small and Medium Enterprises Development Organization of Turkey) and IŞKUR ${ }^{* * *}$ (Turkish Employement Agency). An online survey form was sent to 600 entrepreneurs selected by random sampling method from 31 March - 10 April 2019. There are 555 feedbacks until 12 May 2019. After eliminating 44 incomplete forms, analysis was carried out with 511 forms.

\footnotetext{
* İGESIB is a unit that established to develop university industry cooperation, to guide young entrepreneurs and university students in terms of to provide them with the knowledge, skills, self-confidence and power they will need in business life.

** KOSGEB was established under the Ministry of Science, Industry and Technology in accordance with economic development goals in order to increase the share and efficiency of small and medium-sized enterprises, meet their economic and social needs, increase their competitiveness and levels, and achieve integration with the industry.

*** İŞKUR was established under the Ministry of Family, Labor and Social Services with the aim of assisting in the protection, development, dissemination and prevention of unemployment and implementing active and passive labor policies.
} 


\subsection{Development and Implementation of Scales Used}

The survey form consists of three sections. The first section includes 16 questions about entrepreneurs' demographic information (age, gender, education, income, experience), data on their businesses (sector, market) and intellectual property rights and financial support.

The second part, which measures the creative thinking disposition, is adapted from Özgenel and Çetin (2017). Analyzes were conducted with a questionnaire of 25 items and 72 participants. As a result, a two-factor structure consisting of 16 items constituted. The form explained \%60,42of the total variance. According to the chi-square, corrected chi-square and CFI values, the model fit is good and the RMSEA and SRMR values are very good. According to the obtained data, model fit is quite good and the results are summarized in Table 1 below.

Table 1. Factor Analysis for Creative Thinking Disposition

\begin{tabular}{|c|c|c|c|c|}
\hline $\begin{array}{l}\text { Factor } \\
\text { Name }\end{array}$ & Items & $\begin{array}{c}\text { Factor } \\
\text { Loading }\end{array}$ & $\begin{array}{c}\text { Factor } \\
\text { Explanation } \\
(\%)\end{array}$ & $\begin{array}{c}\text { Reliability } \\
\text { Analysis } \\
\text { (Cronbach's } \\
\text { Alpha) }\end{array}$ \\
\hline \multirow{8}{*}{$\begin{array}{l}\text { Innovative- } \\
\text { ness }\end{array}$} & $\begin{array}{l}\text { I use my imagination to design a new idea, } \\
\text { work or solution. }\end{array}$ & ,797 & \multirow[t]{8}{*}{41,259} & \multirow[t]{8}{*}{, 858} \\
\hline & $\begin{array}{l}\text { I tackle a situation, case or problem in detail } \\
\text { and in depth. }\end{array}$ &, 710 & & \\
\hline & I work disciplined to create an idea or product. & ,668 & & \\
\hline & $\begin{array}{l}\text { I generate useful and original answers or } \\
\text { solutions about problems or situations. }\end{array}$ &, 598 & & \\
\hline & $\begin{array}{l}\text { I accept that a case or a problem may have } \\
\text { multiple causes. }\end{array}$ &, 576 & & \\
\hline & $\begin{array}{l}\text { I link tips on different issues, situations, or } \\
\text { happenings. }\end{array}$ &, 563 & & \\
\hline & $\begin{array}{l}\text { I combine my observations, experience, } \\
\text { knowledge and thoughts to develop ideas. }\end{array}$ &, 555 & & \\
\hline & $\begin{array}{l}\text { I envision the solution of problems, situations } \\
\text { or happenings in my mind. }\end{array}$ &, 525 & & \\
\hline \multirow{4}{*}{$\begin{array}{l}\text { Curiosity } \\
\text { and Risk }\end{array}$} & $\begin{array}{l}\text { I ask the question "I wonder" about a case, } \\
\text { situation or problem that I have encountered. }\end{array}$ & ,762 & \multirow[t]{4}{*}{19,161} & \multirow[t]{4}{*}{, 715} \\
\hline & $\begin{array}{l}\text { I like to deal with cases, situations or things } \\
\text { that I'm curious about or interested. }\end{array}$ &, 733 & & \\
\hline & $\begin{array}{l}\text { Instead of the usual, I prefer the new and the } \\
\text { different. }\end{array}$ &, 724 & & \\
\hline & I am curious about interesting cases, & ,715 & & \\
\hline
\end{tabular}




\begin{tabular}{|c|c|c|c|c|}
\hline \multirow[t]{5}{*}{ Disposition } & \multicolumn{2}{|l|}{ problems, objects or situations. } & & \\
\hline & $\begin{array}{l}\text { I associate unrelated concepts or ideas for a } \\
\text { new purpose. }\end{array}$ & ,706 & & \\
\hline & I try to look at things from different aspects. & ,695 & & \\
\hline & I am curious about what'sgoing on around me. & 657 & & \\
\hline & I am not afraid of to make mistakes. &, 596 & & \\
\hline \multicolumn{3}{|r|}{ TOTAL } & \multicolumn{2}{|l|}{60,42} \\
\hline \multicolumn{2}{|r|}{$\begin{array}{r}\text { Kaiser-Meyer-Olkin Measure of } \\
\text { SamplingAdequacy }\end{array}$} &, 825 & GFI & 0,911 \\
\hline \multicolumn{2}{|r|}{ Bartlett's Test of SphericityChi-square } & 439,238 & AGFI & 0,860 \\
\hline \multicolumn{2}{|r|}{ df } & 120 & CFI & 0,923 \\
\hline \multicolumn{2}{|r|}{$\chi^{2} /$ df ratio } & 3,66 & RMSEA & 0,049 \\
\hline \multicolumn{2}{|r|}{ p value } & 000 & RMR & 0,056 \\
\hline & & & SRMR & 0,021 \\
\hline
\end{tabular}

Although many works related to the subject have been used in the development of the Social Capital Scale, the main ones used in the formation of the items required for the question pool; Ardahan (2012), Uçar (2016), Polatcan (2018), Kuşçu (2006), Şan and Şimşek (2011), Meriç (2014). Analyzes were conducted with a questionnaire of 30 items and 98 participants. The validity and reliability of the form was detected to be high in analyzes and it was found that it had a three-factor structure with 15 items (Table 2).

Table 2. Factor Analysis for Social Capital

\begin{tabular}{|c|c|c|c|c|}
\hline $\begin{array}{l}\text { Factor } \\
\text { Name }\end{array}$ & Items & $\begin{array}{c}\text { Factor } \\
\text { Loadings }\end{array}$ & $\begin{array}{c}\text { Factor } \\
\text { Explanation } \\
(\%)\end{array}$ & $\begin{array}{c}\text { Reliability } \\
\text { Analysis } \\
\text { (Cronbach's } \\
\text { Alpha) }\end{array}$ \\
\hline \multirow{7}{*}{$\begin{array}{l}\text { Linking } \\
\text { Social } \\
\text { Capital }\end{array}$} & $\begin{array}{l}\text { I have important acquaintances in public } \\
\text { institutions and political community. }\end{array}$ & ,933 & \multirow[t]{7}{*}{34,320} & \multirow[t]{7}{*}{, 846} \\
\hline & $\begin{array}{l}\text { I have good relations with university } \\
\text { staff and academics. }\end{array}$ & ,858 & & \\
\hline & $\begin{array}{l}\text { Thanks to the social environment I have, } \\
\text { I can easily solve many of my problems. }\end{array}$ & 850 & & \\
\hline & $\begin{array}{l}\text { I have good communication with people } \\
\text { who are important in business. }\end{array}$ & ,838 & & \\
\hline & $\begin{array}{l}\text { I have famous acquaintances from the } \\
\text { world of media and art and culture. }\end{array}$ & ,836 & & \\
\hline & $\begin{array}{l}\text { I have important acquaintances in } \\
\text { business world. }\end{array}$ & ,789 & & \\
\hline & $\begin{array}{l}\text { I have important connections in } \\
\text { overseas. }\end{array}$ & ,766 & & \\
\hline
\end{tabular}




\begin{tabular}{|c|c|c|c|c|}
\hline \multirow[t]{5}{*}{$\begin{array}{l}\text { Bridging } \\
\text { Social } \\
\text { Capital }\end{array}$} & $\begin{array}{l}\text { I have a broad circle (suppliers, project } \\
\text { partners, customers) in the sector I work } \\
\text { in. }\end{array}$ & ,838 & \multirow[t]{5}{*}{19,209} & \multirow[t]{5}{*}{,828 } \\
\hline & $\begin{array}{l}\text { I make efforts and spend time to } \\
\text { establish new business relationships and } \\
\text { maintain existing ones. }\end{array}$ & ,814 & & \\
\hline & $\begin{array}{l}\text { I am on good terms with people who can } \\
\text { provide critical information where I } \\
\text { work. }\end{array}$ & ,807 & & \\
\hline & $\begin{array}{l}\text { I use my internet and social media } \\
\text { connections effectively. }\end{array}$ & ,798 & & \\
\hline & $\begin{array}{l}\text { I have a wide social environment thanks } \\
\text { to my activities in non-governmental } \\
\text { organizations. }\end{array}$ & ,789 & & \\
\hline \multirow{3}{*}{$\begin{array}{l}\text { Bonding } \\
\text { Social } \\
\text { Capital }\end{array}$} & $\begin{array}{l}\text { Thanks to my family and relatives I have } \\
\text { a wide social environment. }\end{array}$ & ,811 & \multirow[t]{3}{*}{7,981} & \multirow[t]{3}{*}{,817 } \\
\hline & $\begin{array}{l}\text { I have full confidence that my close } \\
\text { friends will help when I need them. }\end{array}$ & ,738 & & \\
\hline & $\begin{array}{l}\text { I have good relations with the neighbors } \\
\text { and artisans in my neighborhood. }\end{array}$ & ,724 & & \\
\hline & & TOTAL & \multicolumn{2}{|l|}{61,51} \\
\hline & $\begin{array}{r}\text { Kaiser-Meyer-Olkin Measure of } \\
\text { SamplingAdequacy }\end{array}$ & ,787 & GFI & 0,93 \\
\hline \multicolumn{2}{|r|}{ Bartlett's Test of SphericityChi-square } & 504,404 & AGFI & 0,92 \\
\hline & df & 105 & CFI & 0,96 \\
\hline & $\chi^{2} /$ df ratio & 4,8 & RMSEA & 0,046 \\
\hline \multicolumn{2}{|r|}{ p value } & ,000 & RMR & 0,035 \\
\hline & & & SRMR & 0,029 \\
\hline
\end{tabular}

Cronbach Alpha value is found to be 0,802 in the Creative Thinking Disposition Scale analysis which was carried out on 486 forms and none of the items were extracted. Cronbach Alpha value is calculated as 0.838 on 497 forms on Social Capital scale and no item removed. In the detailed analysis, it was determined that both scales showed normal distribution. Innovation performance is determined directly by considering industrial property right such as patent, utility model, copyright. Statistical data related to the scales are as follows (Table $3)$. 
Table 3. Statistics on Scales

\begin{tabular}{|c|c|c|c|c|c|}
\hline & \multicolumn{2}{|c|}{$\begin{array}{c}\text { Creative Thinking } \\
\text { Disposition }\end{array}$} & \multicolumn{3}{|c|}{ Social Capital } \\
\hline & Innovation & Curiosity & Linking & Bridging & Bonding \\
\hline \multirow[t]{2}{*}{ Statistics } & Disposition & and Risk & Social & Social & Social \\
\hline & & Disposition & Capital & Capital & Capital \\
\hline $\mathbf{N}$ & 511 & 511 & 511 & 511 & 511 \\
\hline Mean & 80,063 & 81,311 & 61,252 & 52,9628 & 57,364 \\
\hline S.E. of Mean &, 16541 &, 16628 & , 19986 & ,11644 & ,08439 \\
\hline Median & 80 & 82,5 & 62,857 & 52 & 60 \\
\hline Mod & 82,5 & 80 & 60 & 48 & 60 \\
\hline Std. Dev. & 3,73921 & 3,75877 & 4,5179 & 2,63215 & 1,90775 \\
\hline Variance & 13,982 & 14,128 & 20,411 & 6,928 & 3,640 \\
\hline Skewness &,- 090 &,- 132 &,- 067 &,- 066 &, 065 \\
\hline S.E. of Skew. & 018 &, 018 & ,018 &, 018 &, 018 \\
\hline Kurtosis & ,323 &, 351 &,- 071 &,- 002 &,- 117 \\
\hline S.E. of Kurt. & ,216 &, 216 & ,216 &, 216 &, 216 \\
\hline Range & 75,00 & 75,00 & 75,00 & 58,00 & 73,33 \\
\hline Minimum & 25,00 & 25,00 & 25,00 & 30,00 & 20,00 \\
\hline Maximum & 100,00 & 100,00 & 100,00 & 88,00 & 93,33 \\
\hline
\end{tabular}

\subsection{Demographics of Entrepreneurs and Businesses}

In the research sample, the highest frequency (40\%) by age is between $26-35$ age range, and as the rate of entrepreneurs in the 18-45 age range reaches approximately $86 \%$, it can be said that the population is generally young. $39.3 \%$ of respondents have bachelor's degree while the second highest frequency group $(23.3 \%)$ have high school degree. Considering the distribution of entrepreneurs according to their work experience, it is seen that more than half (approximately 54\%) have 11 years and more work experience. It is seen that more than half of the experiences of the entrepreneurs in the sample is in the service sector (approximately $55.6 \%$ ), the second place is the trade sector $(24.5 \%)$, and the manufacturing sector remains at only $20 \%$.

When the rate of establishment of the sample group is examined, it is seen that more than $40 \%$ established the enterprise within 3 years at most, and close to $60 \%$ did not yet own the enterprise. When the companies operating sectors are analyzed, it is seen that almost half of them $(49.5 \%)$ are in service sector while manufacturing $(24.4 \%)$ and trading $(26.1 \%)$ sectors are more balanced. Only $25 \%$ of the participants operate in the international market, while the rest are carried on their business in regional and national markets.

\subsection{Analysis Results}

As seen in Table 4 below, there is a moderate correlation between the sub-dimensions of the 
creative thinking disposition (innovativeness, curiosity and risk disposition) and the sub-dimensions of social capital (linking, bridging, bonding).

Table 4. Correlation Matrix

\begin{tabular}{|c|c|c|c|c|c|c|c|}
\hline & & & 1 & 2 & 3 & 4 & 5 \\
\hline \multirow{2}{*}{ 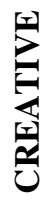 } & \multirow{2}{*}{ 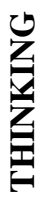 } & 1.Innovation Disposition & 1 & & & & \\
\hline & & 2.Curiosity and Risk Disposition &, $991^{* *}$ & 1 & & & \\
\hline \multirow{3}{*}{$\underset{\circlearrowright}{\circlearrowright}$} & \multirow{3}{*}{$\underset{0}{2}$} & 3.Linking Social Capital &, $406^{* *}$ &, $410^{* *}$ & 1 & & \\
\hline & & 4.Bridging Social Capital &, $410^{* *}$ &, $414^{* *}$ &, $976^{* *}$ & 1 & \\
\hline & & 5.Bonding Social Capital &, $409^{* *}$ & $415^{* *}$ &, $975^{* *}$ &, $935^{* *}$ & 1 \\
\hline
\end{tabular}

**. Correlation is significant at the 0.01 level (2-tailed). $\mathrm{N}=511$

According to the patent application whether they have or not, $t$ test implemented for independent groups to measure. There is a significant difference between the entrepreneurs' creative thinking tendencies and social capital scores (Table 5).

Table 5. Independent Samples Test

\begin{tabular}{|c|c|c|c|c|c|c|c|c|c|}
\hline \multicolumn{2}{|c|}{ Group Statistics } & Patent & $\mathbf{N}$ & \multicolumn{2}{|c|}{ Mean } & \multicolumn{2}{|c|}{ Std. Deviation } & \multicolumn{2}{|c|}{ Std. Error Mean } \\
\hline \multirow{2}{*}{\multicolumn{2}{|c|}{$\begin{array}{l}\text { Creative } \\
\text { Thinking } \\
\end{array}$}} & No & 448 & & 79,4102 & & 9,55541 & & ,45145 \\
\hline & & Yes & 60 & & 83,7292 & & 7,74491 & & ,99986 \\
\hline \multirow{2}{*}{\multicolumn{2}{|c|}{ Social Capital }} & No & 448 & & 56,7973 & & 11,89062 & &, 56178 \\
\hline & & Yes & 60 & & 64,1302 & & 11,88801 & & 1,53474 \\
\hline \multirow{2}{*}{\multicolumn{3}{|c|}{$\begin{array}{c}\text { Independent } \\
\text { Samples } \\
\text { Test }\end{array}$}} & \multicolumn{3}{|c|}{$\begin{array}{c}\text { Levene's Test for } \\
\text { Equality of Variances }\end{array}$} & \multicolumn{4}{|c|}{ t-test for Equality of Means } \\
\hline & & & $\mathbf{F}$ & Sig. & $\mathbf{t}$ & df & $\begin{array}{c}\text { Sig. } \\
\text { (2-tailed) }\end{array}$ & $\begin{array}{c}\text { Mean } \\
\text { Difference }\end{array}$ & $\begin{array}{l}\text { Std. } \\
\text { Error } \\
\text { Diff. }\end{array}$ \\
\hline \multirow{2}{*}{ 串 } & \multirow{2}{*}{ 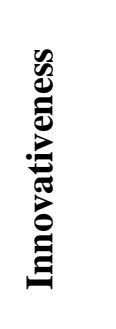 } & $\begin{array}{l}\text { Equal } \\
\text { variances } \\
\text { assumed }\end{array}$ & 1,51 & ,219 & $-1,80$ & 506 & ,043 &,- 92485 & ,51393 \\
\hline & & $\begin{array}{l}\text { Equal var. } \\
\text { not } \\
\text { assumed }\end{array}$ & & & $-2,09$ & 84,51 & ,039 &,- 92485 & ,44123 \\
\hline
\end{tabular}




\begin{tabular}{|c|c|c|c|c|c|c|c|c|c|}
\hline & 을 & $\begin{array}{l}\text { Equal } \\
\text { variances } \\
\text { assumed }\end{array}$ & 1,54 & ,215 & $-1,82$ & 506 & ,048 &,- 94375 &, 51676 \\
\hline & 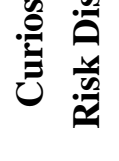 & $\begin{array}{l}\text { Equal var. } \\
\text { not } \\
\text { assumed }\end{array}$ & & & $-2,15$ & 85,30 & ,034 &,- 94375 & ,43894 \\
\hline \multirow{6}{*}{ 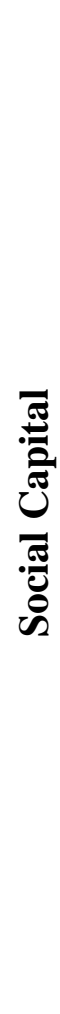 } & \multirow{2}{*}{ 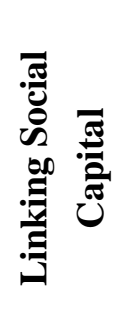 } & $\begin{array}{l}\text { Equal } \\
\text { variances } \\
\text { assumed }\end{array}$ & ,006 & ,939 & $-4,49$ & 506 & ,000 & $-2,73170$ & ,60840 \\
\hline & & $\begin{array}{l}\text { Equal var. } \\
\text { not } \\
\text { assumed }\end{array}$ & & & $-4,48$ & 75,61 &, 000 & $-2,73170$ & 60933 \\
\hline & \multirow{2}{*}{ 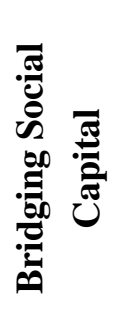 } & $\begin{array}{l}\text { Equal } \\
\text { variances } \\
\text { assumed }\end{array}$ & ,437 & ,509 & $-4,33$ & 506 & ,000 & $-1,53973$ & ,35540 \\
\hline & & $\begin{array}{l}\text { Equal var. } \\
\text { not } \\
\text { assumed }\end{array}$ & & & $-4,24$ & 74,72 &, 000 & $-1,53973$ & ,36315 \\
\hline & \multirow{2}{*}{ 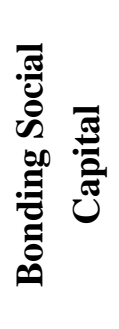 } & $\begin{array}{l}\text { Equal } \\
\text { variances } \\
\text { assumed }\end{array}$ & ,078 & ,780 & $-4,61$ & 506 & ,000 & $-1,18348$ & ,25647 \\
\hline & & $\begin{array}{l}\text { Equal var. } \\
\text { not } \\
\text { assumed }\end{array}$ & & & $-4,49$ & 74,56 & ,000 & $-1,18348$ & ,26304 \\
\hline
\end{tabular}

The average of creative thinking disposition of those who have a patent application and/or owners is 83.7292, while the average of those who are not is 79.4102. Again, the average of social capital of those who have a patent application and / or owners is 64,1302, while the average of those who are not is 56,7973. As it is seen in Table 5, there is an important difference. Since $\mathrm{p}=0.109>0.05$ (creative thinking disposition) and $\mathrm{p}=0.999>0.05$ (social capital) resulting from the Levene test, co-variance assumption is accepted. According to this, there is a significant difference between the creative thinking disposition (Sig.2-tailed $=0.047$ ) and social capital (Sig.2-tailed = 0.032) scores according to the patent application and ownership.

\section{Conclusion and Recommendations}

Among the most important tasks of the entrepreneurs are to provide creative and innovative activities for their enterprises in the face of increasing speed of change and globalization. Entrepreneurship and innovation coincide with the concept of social capital in many respects due to the relationship between countries' growth, development and competitiveness and consequently entrepreneurship ecosystem and innovation systems are coming to the agenda and become more of an issue to develop policies at macro and micro level. In this context, 
examining the relationships between the concepts of social capital, creativity and innovation in entrepreneurship is one of the arguments that this study addresses the issue.

Although entrepreneurs' creative thinking disposition scores are quite high, the low level of data in terms of patents and other intellectual property rights points out to problems in the transformation of creative ideas into innovation. The fact that when entrepreneurs are creative and ambitious in solving problems such as lack of knowledge and skills, inadequacy of time-space and financing, shows that it is highly effective in achieving successful results. In general, although the total number of patents in the sample is low, there is a relationship between the creativity and industrial property rights variable in the data relationship analysis. Therefore, it is thought that the entrepreneurs' use of practices that will increase their creativity levels and techniques to develop creative ideas in particular may increase the innovation performance and competitiveness of their enterprises. Research findings reveal that creative entrepreneurs have higher innovation performances.

Removing the obstacles of transformation of the creative ideas into innovation by developing policies and supporting entrepreneurs financially are inadequate. At the same time, it is thought that the implementation of various practices in order to spread the culture of entrepreneurship and innovation may provide advantage in terms of increasing the country's innovation performance and competitiveness. It is believed that the decision-makers will contribute not only to financial support, but also the steps to be taken in relation to the development of legal, educational and other fields in terms of spreading of developing common project culture, risk capital and angel investors. In addition, arrangements to facilitate the processes of support and reduce the bureaucratic burden will catalyze the combination of the right jobs and the wherewithal. If entrepreneurs have negative thoughts about protecting their innovations and inventions with patents etc. that are meaningless and useless commercially, revealing the reasons and provide solutions will be beneficial in terms of measurability and control.

Research findings demonstrate that social capital affects all both variables -creativity, innovation (patent)- significantly and positively. Social capital is a driving force that triggers other types of capital besides the benefits through its use. Components of social capital -information, influence, control, power and solidarity- and social networks that enable its use, provides capabilities for entrepreneurs to identify opportunities, to generate innovative ideas, develop and provide the necessary resources for success. Entrepreneurs should develop strategies to benefit from the positive opportunities offered by social capital while being protected from negative effects such as exclusion, negative group norms, being closed to new information and methods, discrimination and favoritism.

Social capital is a concept that should be considered in terms of macro policies when taking into account of the findings of research reveals that social capital positively and significantly affects creativity and innovation. In developing countries, the stock of social capital is a byproduct of religion, tradition, common historical background and 
cultural norms and as high as the presence of traditional social groups (lineages, villages, tribes, etc.). By contrast with this conjuncture, formations that serve as larger economic and political organizations are lacking in these societies. Social capital cannot be meaningful solely by ignoring the importance of education, science, information and communication technologies, innovation and creativity may not make sense. Thus, developing policies by embracing the relations between all these concepts integratedly can be beneficial in achieving the desired results. Although these results coincide with the findings of past studies in Turkey, the vast majority of domestic research focuses on the positive aspects of social capital. For future research implementation it is possible to examine potential negative aspects of the concept. Researching at which stage of the process of creativity (preparation, incubation, illumination, verification) and innovation (identifying opportunities, creating ideas, conceptualizing, prototyping, production, marketing), which social capital type (bonding, bridging, linking) is effective can contribute to the field.

\section{References}

Adler, P. S., \& Kwon, S. W. (2002). Social Capital: Prospects for a New Concept. The Academy of Management Review, 27(1). 17-40. https://doi.org/10.5465/amr.2002.5922314

Ahmad, N., \& Seymour, R. G. (2008). Defining Entrepreneurial Activity: Definitions Supporting Frameworks for Data Collection, OECD Statistics Working Papers 2008/1, OECD Publishing. https://doi.org/10.1787/18152031

Ahn,S.Y.\& Kim, S.H.(2017).What Makes Firms Innovative? The Role of Social Capital in Corporate Innovation, Sustainability. 9(9):1564. https://doi.org/10.3390/su9091564

Alexy, O. T., Block, J. H., Sandner, P., \& Ter Wal, A. L. J. (2012). Social capital of venture capitalists and start-up funding, Small Business Economics, 39(4), 835-851. https://doi.org/10.1007/s11187-011-9337-4

Antoniou, A. S., Cooper, C., \& Gatrell, C. (2019). Women, Business and Leadership: Gender and Organizations, Cheltenham, UK: Edward Elgar Publishing

Ardahan, F. (2012). Sosyal Sermaye Ölçeği: Geçerlilik, Güvenirlilik Çalışması. International Journal of Human Sciences, 9(2), 773-789

Audretsch, D. B. (2003). Entrepreneurship A survey of the literatüre, Brussels: European Commission Enterprise Directorate-General Enterprise Papers No 14, January

Baker, M., Rudd, R., \& Pomeroy, C. (2001). Relationships between Critical and Creative Thinking. Journal of Southern Agricultural Education Research, 51(1), 173-188

Banks, G. (2003). Social Capital: Reviewing the Concept and its Policy Implications, Melbourne: Commonwealth of Australia Productivity Commission Research Paper 
Barlın, H. (2010). Bölgesel İktisat Politikaları ve Türkiye Uygulamaları, Doktora Tezi, Marmara Üniversitesi Sosyal Bilimler Enstitüsü, İstanbul

Baudeau, N. (1910). Premiere introduction a laphilosophie economique, edited by A. Dubois. Paris: P. Geuthner [originally 1767]

Berry, H. L., \& Welsh, J. A. (2010). Social capital and health in Australia: An overview from the household, income and labour dynamics in Australia survey". Social Science \& Medicine, 70, 588-596. https://doi.org/10.1016/j.socscimed.2009.10.012

Bourdieu, P. (1986). The Forms of Capital, Handbook of Theory and Research for the Sociology of Education, J. G. Richardson (ed.), New York: Greenwood Press, 241-258

Brouard, F., \& Larivet, S. (2010). Essay of clarifications and definitions of the Related concepts of social enterprise, entrepreneur and Entrepreneurship", Handbook of Research on Social Entrepreneurship, Alain Fayolle, Harry Matlay, (eds.), Cheltenham, UK: Edward Elgar Publishing, 2010, 29-56.

Brush, C. G., Greene, P. G., Hart, M. M., \& Haller, H. S. (2001).From Initial Idea to Unique Advantage: The Entrepreneurial Challenge of Constructing a Resource Base. The Academy of Management Executive, 15(1), 64-80

Cabello-Medina, C., Lo'pez-Cabrales, A., \& Valle-Cabrera, R.(2011).Leveraging the innovative performance of human capital through HRM and social capital in Spanish firms". The International Journal of Human Resource Management, 22(4), 807-828. https://doi.org/10.1080/09585192.2011.555125

Cantillon, R. (2010). An Essay on Economic Theory, Translated by Chantal Saucier, Edited by Mark Thornton, Alabama: Ludwig von Mises Institute.

Carnall, C. (2007). Managing Change in Organizations, Fifth Edition, Harlow, England: Prentice Hall Financial Times \& Pearson Education

Chakrabarti, A. K., \& Santoro, M. D. (2004). Building social capital and learning environment in university - industry relationships, International Journal of Learning and Intellectual Capital, 1(1), 19-36. https://doi.org/10.1504/IJLIC.2004.004421

Chell, E. (2007). Social Enterprise and Entrepreneurship: Towards a Convergent Theory of the Entrepreneurial Process. International Small Business Journal, 25(1), 5-26. https://doi.org/10.1177/0266242607071779

Cohen, D., \& Prusak, L. (2001). In Good Company: How Social Capital Makes Organizations Work, Brighton, Massachusetts: Harvard Business School Press.

Cohen, S., \& Fields, G. (1999). Social Capital and Capital Gains in Silicon Valley, California Management Review, 41(2), 108-130. https://doi.org/10.2307/41165989

Collier, P. Social Capital and Poverty, Social Capital Initiative Working Paper No. 4, 
Washington, DC: The World Bank Social Development Family Environmentally and Socially Sustainable Development Network, December.

Cooper, A., Gimeno-Gascón, F. J.\& Woo, C. Y. (1997). Initial Human and Financial Capital as Predictors of New Venture Performance, The Journal of Private Equity, 1(2), 371-395.

Dinovitzer, R. (2006). Social Capital and Constraints on Legal Careers. Law \& Society Review, 40(2), 445-479. https://doi.org/10.1111/j.1540-5893.2006.00268.x

Dornberger, U., \& Suvelza G. J. A. (2012). Managing the Fuzzy Front-End of Innovation, Leipzig, Germany: Intelligence 4 Innovation International SEPT Program, the Leipzig University

Düzgün, A. N. (2018). Türkiye'deki Suriyeli Göçmen Kadınların Savaş Öncesi ve Sonrası Sahip Oldukları Sosyal Sermaye Değişiminin Araştırılması, Yüksek Lisans Tezi, İstanbul Üniversitesi Sosyal Bilimler Enstitüsü, İstanbul

Erdem, F. (2003). Örgütsel Yaşamda Güven, Sosyal Bilimlerde Güven, Ferda Erdem (ed.), Ankara: Vadi Yayınları

Ergen, M. (2014). Girişimci Kapital: Silikon Vadisi Tarihi ve Startup Ekonomisi, İstanbul: Koç Üniversitesi Yayınları

Eşki, H. (2010). SosyalSermaye: Kişisel ve Kurumsal Gelişmeye Farklı Bir Yaklaşım, Ankara: Orion.

Esterling, L., Farrior, A., Joyce, E., McAllister, G., McLaurin, C., Ruckdeschel, L., Stimson, H., \& Williams, J. (2009). Capital Opportunities for Small Businesses A Guide to Financial Resources for Small Business in North Carolina, Raleigh, NC: Small Business \& Technology Development Center

Fazio, G., \& Lavecchia, L. (2013). Social Capital Formation across Space: Proximity and Trust in European Regions. International Regional Science Review, 36(3), 296-321. https://doi.org/10.1177/0160017613484928

Ferlander, S. (2007). The Importance of Different Forms of Social Capital for Health. Acta Sociologica, 50(2), 115-128. https://doi.org/10.1177/0001699307077654

Fine, B. (2010). Theories of Social Capital: Researchers Behaving Badly, IIPPE, New York: Pluto Press.

Foster, K. A., Smith, R. J., Bell, B. A., \& Shaw, T. C. (2019). Testing the Importance of Geographic Distance for Social Capital Resources. Urban Affairs Review, 55(1), 231-256. https://doi.org/10.1177/0001345519889723

Fransman, M. Models of Innovation in Global ICT Firms: The Emerging Global Innovation Ecosystems, Joint Research Centre: Institute for Prospective Technological 
Studies, Luxembourg: Publications Office of the European Union

Fukuyama, F. (2000). Social Capital and Civil Society, IMF Institute Working Paper 74

Gandhi, T., \& Raina, R. (2018). Social entrepreneurship: the need, relevance, facets and constraints. Journal of Global Entrepreneurship Research, 8(1), 1-13. https://doi.org/10.1186/s40497-018-0094-6

Gargiulo, M., \& Benassi, M. (2000). Trapped in Your Own Net? Network Cohesion, Structural Holes, and the Adaptation of Social Capital. Organization Science, 11(2), 183-196. http://dx.doi.org/10.1287/orsc.11.2.183.12514

Gariboldi, A., \& Catellani, N. (2013). The national narratives about Creativity, Creativity in pre-school education, Italy: SERN, 20-47.

Gittell, R., \& Vidal, A. (1998). Community Organizing: Building Social Capital as a Development Strategy. Newbury Park, CA: Sage Publications. http://dx.doi.org/10.4135/9781452220567

Granovetter, M. S. (1973). The Strength of Weak Ties. American Journal of Sociology, 78(6), 1360-1380.

Guilford, J. P. (1966). Measurement and Creativity, Theory Into Practice. Creativity, 5(4), 186-189. https://doi.org/10.1080/00405846609542023

Hambrick, D. C., \& Mason, P. A. (1984).Upper Echelons: The Organization as a Reflection of Its Top Managers. The Academy of Management Review, 9(2), 193-206. https://doi.org/10.2307/258434

Hartmann, D. (2014). Linking economic complexity and human development: How economic diversification and social networks affect human agency and welfare, Routledge Studies in Development Economics No.110, London: Taylor and Francis. https://doi.org/10.1016/j.worlddev.2016.12.020

Hawkins R. L., \& Maurer, K. (2010). Bonding, Bridging and Linking: How Social Capital Operated in New Orleans following Hurricane Katrina. British Journal of Social Work, 40, 1777-1793, https://doi.org/10.1093/bjsw/bcp087

Healy, A., Perkmann, M., Goddard, J., \& Kempton, L. (2014). Measuring the impact of university-business cooperation: Final Report, Luxembourg: Publications Office of the European Union.

Henriques, I. C., Sobreiro, V. A., \& Kimura, H. (2018). Science and technology park: Future challenges. Technology in Society, 53, 144-160. https://doi.org/10.1016/j.techsoc.2018.01.009

Herron, D. G., \& Herron, L. (1991). Entrepreneurial nursing as a conceptual basis for in-hospital nursing practice models. Nursing Economics, 9(5), 310-316 
Hudson, L., \& Chapman, C. (2002). The Measurement of Social Capital in the United States, the International Conference on Social Capital Measurement, London, September

Jong, J. D., \& Wennekers, S. (2008). Intrapreneurship conceptualizing entrepreneurial employee behaviour, Zoetermeer, Netherlands: Scales.

Kang, S., \& Na, Y. K. (2018). The Effect of the Relationship Characteristics and Social Capital of the Sharing Economy Business on the Social Network, Relationship Competitive Advantage, and Continuance Commitment. Sustainability, 10(2203), 1-22. https://doi.org/10.3390/su10072203

Karaömer, M., (2014). Hatay İli Kırsalındaki Kadınların Girişimcilik Eğilimlerinin İncelenmesi, Yüksek LisansTezi, Gaziosmanpaşa Üniversitesi Fen Bilimleri Enstitüsü, Tokat.

Kirzner, I. M. (1973). Competition and Entrepreneurship, Chicago: University of Chicago Press.

Knight, F. H. (2014). Risk, Uncertainty and Profit, Eastford CT: Martino Fine Books.

Kuşcu, M. K. (2006). İş Yaşamında Sosyal Sermayenin Çalışanın Fiziksel ve Ruh Sağlığındaki Yeri, Yüksek Lisans Tezi, Marmara Üniversitesi Sağlık Bilimleri Enstitüsü, İstanbul

Lai, K. P., Nathan, R. J., Tan, K. S., \& Chan, B. B. (2010). Effect of Innovation to the Success of Female Entrepreneurs. Journal of Innovation Management in Small and Medium Enterprises, IBIMA Publishing, 2010, 1-14. https://doi.org/10.5171/2010.369877

Lins, K. V., Servaes H., \& Tamayo, A. (2017). Social Capital, Trust, and Firm Performance: The Value of Corporate Social Responsibility during the Financial Crisis. The Journal of Finance, 70(4), 1785-1823. https://doi.org/10.1111/jofi.12505

Lowenfeld, V. (1957). Creative and mental growth (3rd ed.). New York: MacMillan.

Lowenfeld, V. (1960). Creative intelligence. Studies in Art Education, 1(2), 22-25.

Lucky, E. U. (2012). Is Small and Medium Enterprise (SME) an Entrepreneurship? International Journal of Academic Research in Business and Social Sciences, 2(1), 341-352

Mason, C., \& Brown, R. (2014). Entrepreneurial Ecosystems and Growth Oriented Entrepreneurship, OECD LEED Programme and the Dutch Ministry of Economic Affairs Workshop Paper, January.

Melé, D. (2003). Organizational Humanizing Cultures: Do They Generate Social Capital. Journal of Business Ethics, 45(1/2), 3-14. https://doi.org/10.1023/A:1024112226673 
Meriç, Ö. (2014). Dijital Demokrasi: Türkiye'de Yeni Medya ve Siyasal Katılım, Doktora Tezi, Maltepe Üniversitesi Sosyal Bilimler Enstitüsü, İstanbul.

Milana, E., \& Maldaon, I. (2015). Social Capital: A Comprehensive Overview at Organizational Context. Periodica Polytechnica Social and Management Sciences, 23(2), 133-141. https://doi.org/10.3311/PPso.7763

Mishra, A. (2013). Role of Government in Developing Entrepreneurs. AISECT University Journal, 2(4), 1-4.

Mort, G. S., Weerawardena, J., \& Carnegie, K. (2003). Social Entrepreneurship: Towards Conceptualisation. International Journal of Nonprofit and Voluntary Sector Marketing, 8(1), 76-88. https://doi.org/10.1002/nvsm.202

Mowery, D. C., \& Oxley, J. E. (1995) Inward technology transfer and competitiveness: the role of national innovation systems. Cambridge Journal of Economics, 19(1), 67-93.

Muir, J. (2011). Bridging and Linking in a Divided Society: A Social Capital Case Study from Northern Ireland. Urban Studies, 48(5). 959-976. https://doi.org/10.1177/0042098010368577

Nahapiet, J., \& Ghoshal, S.(1998). Social Capital, Intellectual Capital, and the Organizational Advantage. The Academy of Management Review, 23(2), 242-266. https://doi.org/10.2307/259373

Narayan, D. (1999). Bonds and Bridges: Social Capital and Poverty, Washington, D.C: Poverty Group Prem World Bank

Neidhardt, J. (2018). Social Capital from an Individual Perspective, University of Hohenheim Faculty of Business, Economics and Social Sciences Institute of Economics Chair of Environmental Economics, Regulatory and Consumer Policy, Stuttgart

Newman, L., \& Dale, A.(2005).The role of agency in sustainable local community development. Local Environment, 10(5), 477-486. https://doi.org/10.1080/13549830500203121

OECD. (2011). Fostering Innovation to Address Social Challenges: Workshop Proceedings, Paris, France: OECD Innovation Strategy.

OECD-Eurostat. (2005). Oslo Manual: Guidelines for Collecting and Interpreting Innovation Data, 3. Edition, Organization For Economic Co-Operation and Development Statistical Office Of The European Communities, Paris, France: OECD

Osorio, V. M., \& Buitrago, W. S. V. (2018). Mapping Creativity and Design within the Entrepreneurship Ecosystem. Proceedings of the International Conference on Creativity and Innovation, Osaka, Japan, September 10-12, 27-40

Özdemir, A. A. (2007). Sosyal Ağ Özellikleri Bakış Açısıyla Sosyal Sermaye ve Bilgi 
Yaratma İlişkisi, Doktora Tezi, Anadolu Üniversitesi Sosyal Bilimler Enstitüsü, Eskişehir

Özgenel, M., \& Çetin, M. (2017). Marmara Yaratıcı Düşünme Eğilimleri Ölçeğinin Geliştirilmesi: Geçerlik ve Güvenirlik Çalışması. Marmara Üniversitesi Atatürk Ĕgitim Fakültesi Ĕ̆itim Bilimleri Dergisi, 46(46), 113-132

Patulny, R. V., \& Svendsen, G. L. H. (2007) Exploring the social capital grid: bonding, bridging, qualitative, quantitative. International Journal of Sociology and Social Policy, 27(1/2), 32-51. http://dx.doi.org/10.1108/01443330710722742

Paxton, P. (2002). Social Capital and Democracy: An Interdependent Relationship. American Sociological Review, 67(2), 254-277. https://doi.org/10.2307/3088895

Pilinkiene, V., \& Maciulis, P. (2014).Comparison of different ecosystem analogies: the main Economic determinants and levels of impact. Procedia - Social and Behavioral Sciences, 156, 365-370. http://dx.doi.org/10.5751/ES-05551-180426

Polatcan, M. (2018). Okullarda Sosyal Sermaye Ölçeği: Bir Ölçek Geliştirme Çalışması. Uluslararası Türkçe Edebiyat Kültür Eğitim Dergisi, 7(4), s.2721-2732. https://doi.org/10.7884/teke.4338

Poortinga, W. (2012).Community resilience and health: The role of bonding, bridging, and linking aspects of social capital. Health \& Place, 18(2), 286-295. https://doi.org/10.1016/j.healthplace.2011.09.017.

Portes, A. (1998). Social Capital: Its Origins and Applications in Modern Sociology. Annual Review of Sociology, 24, 1-24. https://doi.org/10.1146/annurev.soc.24.1.1

Putnam, R. D. (2000). Bowling Alone: the Collapse and Revival of American Community, New York: Simon and Schuster. https://doi.org/10.1145/358916.361990

Reynolds, P., Bosma, N., Autio, E., Hunt, S., Bono, N.D., Servais, I., Lopez-Garcia, P., \& Chin, N. (2005), "Global Entrepreneurship Monitor: data collection design and implementation 1998-2003”. Small Business Economics, 24, 205-231. https://doi.org/10.1007/s11187-005-1980-1

Runco, M. A. (1993). Creativity as an Educational Objective for Disadvantaged Students, The National Research Center On The Gifted and Talented, Creativity: Research-Based Decision Making Series 9306

Sadler-Smith, E. (2015). Wallas' Four-Stage Model of the Creative Process: More Than Meets the Eye?. Creativity Research Journal, 27(4), 342-352. https://doi.org/10.1080/10400419.2015.1087277

Şan, M. K., \& Şimşek, R. (2011), Sosyal Sermaye Kavramının Tarihsel - Sosyolojik Arkaplan1. Akademik Incelemeler Dergisi, 6(1), 88-110. 
Say, J. B. (2017). A Treatise on Political Economy: Or the Production, Distribution and Consumption of Wealth, Clement Cornell Biddle (Translator), South Carolina: Create Space Independent Publishing Platform

Schumpeter, J. A. (1934). The Theory of Economic Development, Cambridge: Harvard University Press

Schumpeter, J. A. (1939). Business Cycles: A Theoretical, Historical and Statistical Analysis or the Capitalist Process. New York: McGraw Hill Book Company

Schumpeter, J. A. (1950). Capitalism, Socialism, and Democracy, Third Edition, New York: Harper and Brothers Publishers, 1950

Shi, H. X., Shepherd, D. M., \& Schmidts, T. (2015). Social Capital in Entrepreneurial Family Businesses: The Role of Trust. International Journal of Entrepreneurial Behavior and Research, 21(6), 814-841

Smith, A. (2007). An Inquiry into the Nature and Causes of the Wealth of Nations, Amsterdam: Meta Libri

Staveren, I. V., \& Knorringa, P. (2007). Unpacking Social Capital in Economic Development: How Social Relations Matter. Review of Social Economy, 65(1), 107-135. https://doi.org/10.1080/00346760601132147.

Sternberg, R. J. (2000). Patterns of Giftedness: A Triarchic Analysis, Roeper Review, 22(4), 231-235. https://doi.org/10.1080/02783190009554044

Stuart, T. E., \& Sorenson, O. (2006). Social Networks and Entrepreneurship, The Handbook of Entrepreneurship: Interdisciplinary Perspectives, Sharon A. Alvarez, Rajshree Agarwal ve Olav Sorenson (eds.), New York: Springer, 233-252. https://doi.org/10.1007/0-387-23622-8_11

Szreter, S., \& Woolcock, M. (2004). Health by Association? Social Capital, Social Theory, and the Political Economy of Health. International Journal of Epidemiology, 33(4), 650-667. https://doi.org/10.1093/ije/dyh013.

Szreter, S. (2002). The State of Social Capital: Bringing Back in Power, Politics, and History. Theory and Society, 31(5), 573-621. https://doi.org/10.2105/ajph.92.5.722

Theodoraki, C., Messeghem, K., \& Rice, M. P. (2018). A social capital approach to the development of sustainable entrepreneurial ecosystems: an explorative study. Small Business Economics, 51(1), 153-170. https://doi.org/10.1007/s11187-017-9924-0

Torrance, E. P., \& Safter, H. T. (1999). Making the creative leap beyond. Buffalo, NY: Creative Education Foundation.

Torrance, E. P. (1965). Scientific Views of Creativity and Factors Affecting its Growth. Daedalus, 94(3), 663-681 


\section{Macrothink}

Tura, T., \& Harmaakorpi, V. (2005). Social Capital in Building Regional Innovative Capability. Regional Studies, 39(8), $1111-1125$. https://doi.org/10.1080/00343400500328255

Uçar, E. (2016). Sosyal Sermaye Ölçeğinin Geçerlik ve Güvenirlik Çalışması, Ihlara Ĕ̈itim Araştırmaları Dergisi, 1(1), 1-23

Wallas, G. (1926). The Art of Thought, London: Jonathan Cape

Westlund, H., Andersson, M., \& Karlsson, C. (2013). Creativity as an integral element of social capital and its role for economic Performance, CESIS E-Working Paper Series No.330. https://doi.org/10.4337/9781781004432.00010

Yavan, N. (2018). AR-GE, Yenilik, Girişimcilik, Ticarileştirme ve Yatırım Destekleri El Kitabı, KOP Bölge Kalkınma İdaresi Başkanlığı Girişimcilik ve Yenilik İhtiyaç Analizi Araştırma Projesi Yayını, Ankara: Kalkınma Bakanlığı.

\section{Copyright}

Copyright for this article is retained by the author(s), with first publication rights granted to the journal.

This is an open-access article distributed under the terms and conditions of the Creative Commons Attribution license (http://creativecommons.org/licenses/by/4.0/). 